\title{
Left lateral position and common gynecologic examining position in anal manometry measurements for evaluation of urogynecologic patients
}

\author{
Selçuk Selçuk ${ }^{1}$, Çetin Çam², Mehmet Reşit Asoğlu ${ }^{3}$, Ateş Karateke ${ }^{1}$ \\ 'Department of Obstetrics and Gynecology, Zeynep Kamil Hospital, Istanbul, Turkey \\ ${ }^{2}$ Department of Urogynecology, Zeynep Kamil Hospital, Istanbul, Turkey \\ ${ }^{3}$ Department of Oncology, MD Anderson Cancer Center, Houston, USA
}

\section{Abstract}

Objective: The aim of this study is to compare the anometrical parameters obtained in the left lateral position, which is the conventional position of anal manometry, with the same measurements taken in the common gynecologic examining position $\left(45^{\circ}\right.$ sitting position in a birthing chair with maximum hip flexion).

Material and Methods: Twenty-one patients with lower urinary tract symptoms (LUTS) were enrolled into this prospective cohort study. Basal mean resting pressure (BMRP), maximum squeeze pressure (MSP), rectal sensation, rectal compliance, and recto-anal inhibitory reflex (RAIR) were compared between the gynecologic examining position and left lateral position.

Results: There was no statistically difference between the anal manometric measurements of the left lateral and gynecologic examining positions (paired t-test, $\mathrm{p}>.05$ ).

Conclusion: It can be concluded that it seems to be unnecessary to change the examination chair and/or patient position in urogynecological patients who need an anorectal assessment. (J Turk Ger Gynecol Assoc 2014; 15: 243-4)

Key words: Anal manometry, lower urinary tract symptoms, gynecologic examining position

Received: 03 July, 2015

Accepted: 23 October, 2014

\section{Introduction}

The reported prevalence of anal incontinence in women with urogynecologic problems ranges from $20 \%$ to $54 \%$; therefore, the significance of anorectal function assessment has become more important in the evaluation of patients suffering from urogynecologic problems $(1,2)$. Among the various tests that are available, anorectal manometry is an essential clinical tool. Anorectal manometry has almost always been performed with the patient in the left lateral position $(3,4)$. However, the left lateral position does not permit one to examine the pelvic organs properly and is not suitable for a urogynecologic evaluation. Ideally, assessing the condition of a patient with urogynecological complaints should be in a one-step fashion, with minimal discomfort and without unnecessary time and costs. Changing the patient's position and the examination chair while performing a urogynecological examination causes discomfort, time loss, and additional costs.

The aim of this study is to compare the anometrical parameters obtained in the left lateral position, which is the conven- tional position of anal manometry, with the same measurements taken in the common gynecologic examining position ( $45^{\circ}$ sitting position in a birthing chair with maximum hip flexion), which is the standard of a urogynecological investigation.

\section{Material and Methods}

This prospective cohort study included 21 patients with lower urinary tract symptoms (LUTS). The study was approved by the hospital's ethics committee. Informed consent forms were obtained from all patients. All patients underwent anorectal manometry (Rectoscan, Aymed, İstanbul, Turkey). Each patient was investigated first in the left lateral and then in the gynecologic examining position. Anorectal manometry measurements included basal mean resting pressure (BMRP), maximum squeeze pressure (MSP), rectal sensation, rectal compliance, and recto-anal inhibitory reflex (RAIR). The manometric catheter used was a water-perfused, 4-mm, four-channeled, polyvinyl chloride catheter (Aymed, İstanbul, Turkey). The catheter was connected to a pneumohydraulic capillary infusion system. Each capillary tube was connected 
Table 1. The anal manometric measurements of left lateral and gynecologic examining position

\begin{tabular}{|l|c|c|c|}
\hline & Left lateral position & Gynecologic examining position & p \\
\hline Basal mean resting pressure (mmHg) & $54.4 \pm 12.9$ & $53.9 \pm 17.2$ & .860 \\
\hline Maximum squeeze pressure (mmHg) & $85.2 \pm 31.3$ & $91.6 \pm 30.6$ & .152 \\
\hline Rectal compliance (cc/mmHg) & $13.1 \pm 2.4$ & .542 & .684 \\
\hline First sensation volume (cc) & $40.6 \pm 11.2$ & $71.3 \pm 12.7$ & .053 \\
\hline First urge volume (cc) & $69.1 \pm 14.6$ & $109.7 \pm 24.9$ & .125 \\
\hline Modest sensation volume (cc) & $102 \pm 18.2$ & $180.6 \pm 18.7$ & .847 \\
\hline Maximum tolerated volume (cc) & $180 \pm 19.3$ & \\
\hline \multicolumn{2}{|l}{ The Paired t-test was used. P<0.05 was statistically significant. } \\
\hline
\end{tabular}

to a computer via a Digitrap. A continuous pull-through technique was used to perform the manometry. BMRP, MSP, rectal sensation, rectal compliance, and the presence of RAIR and vector volume were measured in all patients in both positions. The statistical analysis was performed using Statistical Package for the Social Sciences (SPSS) v. 11.5 for Windows (SPSS, Inc., Chicago, IL, USA). Paired t-test was used to assess the difference between paired datasets. $\mathrm{P}<.05$ was considered to be statistically significant.

\section{Results}

The mean age of the patients was $50.2 \pm 3.4$ years. There were no statistical differences between BMRP, MSP, the presence of RAIR, rectal compliance, and rectal sensations obtained in the left lateral position and in the common gynecologic examining position (Table 1). The additional time required to change the examination chair and patient position was $3.6 \pm .92$ minutes.

\section{Discussion}

In the present study, there were no significant changes in manometric variables, including BMRP, MSP, RAIR, rectal compliance, and rectal sensation between the left lateral and common gynecologic examining positions.

The effect of body position on anal manometric parameters has been widely investigated in the medical literature. Comparative studies of the conventional anometric left lateral position with the erect and/or sitting positions have been reported with various results $(4,5)$. To our knowledge, the present study is the first to compare the left lateral position with the standard gynecologic position in women with LUTS. The results of this study show that the gynecological examining position is as reliably effective as the left lateral position in assessing anorectal functions in women with LUTS. Not altering the patient's examination chair and position resulted in less time spent and less discomfort, also allowing the examination of the patient in one-step fashion. Furthermore, women with LUTS are commonly elder people, usually with some physical restrictions, causing difficulties while changing their positions. Often, a health professional is needed to help the patient overcome these physical problems in these women. The rectoanal assess- ment is becoming more and more a part of the examination in women with LUTS. This study shows that performing an anorectal examination in the gynecologic examining position in women with LUTS is practical and has many benefits. This approach will allow one to evaluate a patient by means of the POP-Q system and urodynamics and anorectal manometry without interfering with the patient's comfort in less time. It can be concluded that it seems to be unnecessary to change the examination chair and/or patient position in urogynecological patients who need an anorectal assessment.

Ethics Committee Approval: Ethics committee approval was received for this study.

Informed Consent: Written informed consent was obtained from patients who participated in this study.

Peer-review: Externally peer-reviewed.

Author contributions: Concept - S.S., Ç.Ç.; Design - S.S., Ç.Ç.; Supervision - A.K.; Resource - M.R.A.; Materials - Ç.Ç.; Data Collection\&/ or Processing - M.R.A., S.S., Ç.Ç.; Analysis\&/or Interpretation - M.R.A., S.S., Ç.Ç.; Literature Search - S.S., Ç.Ç.; Writing - S.S., Ç.Ç.; Critical Reviews - S.S., C.C.., A.K.

Conflict of Interest: No conflict of interest was declared by the authors.

Financial Disclosure: The authors declared that this study has received no financial support.

\section{References}

1. Meschia M, Buonaguidi A, Pifarotti P, Somigliana E, Spennacchio $\mathrm{M}$, Amicarelli F. Prevalence of anal incontinence in women with symptoms of urinary incontinence and genital prolapse. Obstet Gynecol 2002; 100: 719-23. [CrossRef]

2. Soligo M, Salvatore S, Milani R, Lalia M, Malberti S, Digesu GA, Mariani S. Double incontinence in urogynecologic practice: A new insight. Am J Obstet Gynecol 2003; 189: 438-43. [CrossRef]

3. Pedersen IK, Christiansen J. A study of the physiological variation in anal manometry. Br J Surg 1989; 76: 69-70. [CrossRef]

4. Yoshioka K, Keighley MR. The position of the patient does not adversely influence the results of the most clinically important measurements of anorectal function. Int J Colorectal Dis 1995; 10: 47-8. [CrossRef]

5. Thekkinkattil DK, Lim MK, Nicholls MJ, Sagar PM, Finan PJ, Burke DA. Contribution of posture to anorectal manometric measurements: are the measurements in left-lateral position physiologic? Dis Colon Rectum 2007; 50: 2112-9. [CrossRef] 